\title{
СТАН КОРУПЩІЙНОї ЗЛОЧИННОСТІ В ОБОРОННО-ПРОМИСЛОВОМУ КОМПЛЕКСІ УКРАїНИ
}

\author{
КОЖУШКО Сергій Олександрович - аспірант Харківського національного \\ університету внутрішніх справ
}

УДК 343.9

DOI 10.32782/NP.2021.4.17

\begin{abstract}
Стаття присвячена дослідженню сучасного стану корупційної злочинності в оборонно-промисловому комплексі Украйни. Встановлено та надано опис рівню, динаміщзі изього виду злочинності в контексті загальної економічної злочинності та економічної злочинності у сбері оборони. Охарактеризовано найбільш поширені корупиійні схеми. Виявлено та аргументовано відтворення корупційної злочинності в ОПК як на нижчому (об’єктовому), середнъому, так і вищому, системному, інституиіоналізованому рівнях.

Ключові слова: оборонно-промисловий комплекс, економічна злочинність, організована злочинність, стан, корупиія, корупиійна схема.
\end{abstract}

Постановка проблеми

Сучасний оборонно-промисловий комплекс (далі - ОПК) України є тією галуззю економіки, яка не лише репрезентує чи не найбільш інноваційні компоненти вітчизняної системи господарства, а й формує науково-виробничий базис суверенізації державної влади у їі спроможності забезпечити потреби Українського війська у техніці, озброєнні як факторів стримання та відсічі збройної агресії РФ. Саме тому злочинність в ОПК підриває засадничі структури національної безпеки, підвищуючи колективну віктимність українського народу щодо злочинів агресії, воєнних та інших злочинів. Тож існує необхідність у розробці ефективних заходів протидії злочинності в ОПК, а надто їі корупційному сегментові, зважаючи на іiї потужний латентно деструктивний потенціал. Але реалізації цього кроку має передувати науковий опис та пояснення стану цієї злочинності.

Зауважимо, що проблеми протидії злочинності в ОПК, корупційній злочинності неодноразово порушувалися у працях О. М. Бандурки, О. Ю. Бусол, І. М. Довбаня, О. Г. Кальмана, О. М. Аитвинова, В. А. Ліпкана, М. І. Панова, В. В. Сазонова, О. О. Степанченка та інших кримінологів, криміналістів. Визнаючи грунтовність та наукову значущість наявних напрацювань, слід також визнати і те, що вони потребують осучаснення, подальшого вдосконалення, а головне - специфікації під предметність корупційних кримінальних практик в ОПК.

Мета статті - встановлення та науковий опис стану корупційної злочинності в ОПК України.

Виклад основного матеріалу

У кримінологічному значенні ОПК може розглядатися як своєрідне ресурсне поле, що зумовлює існування в ньому перш за все економічної злочинності. Дійсно, ОПК колосальна за обсягами грошового обороту сфера господарських відносин. I ця обставина за визначенням, тобто іманентно, формує своєрідне криміногенно-гравітаційне середовище, притягує до себе кримінальний інтерес, що, у тому числі, знаходить своє відображення у і в офіційній державній статистичній звітності (див. діаграму 1). 
Діаграма 1

Графічне зображення рівня і динаміки економічної злочинності у сфері оборони

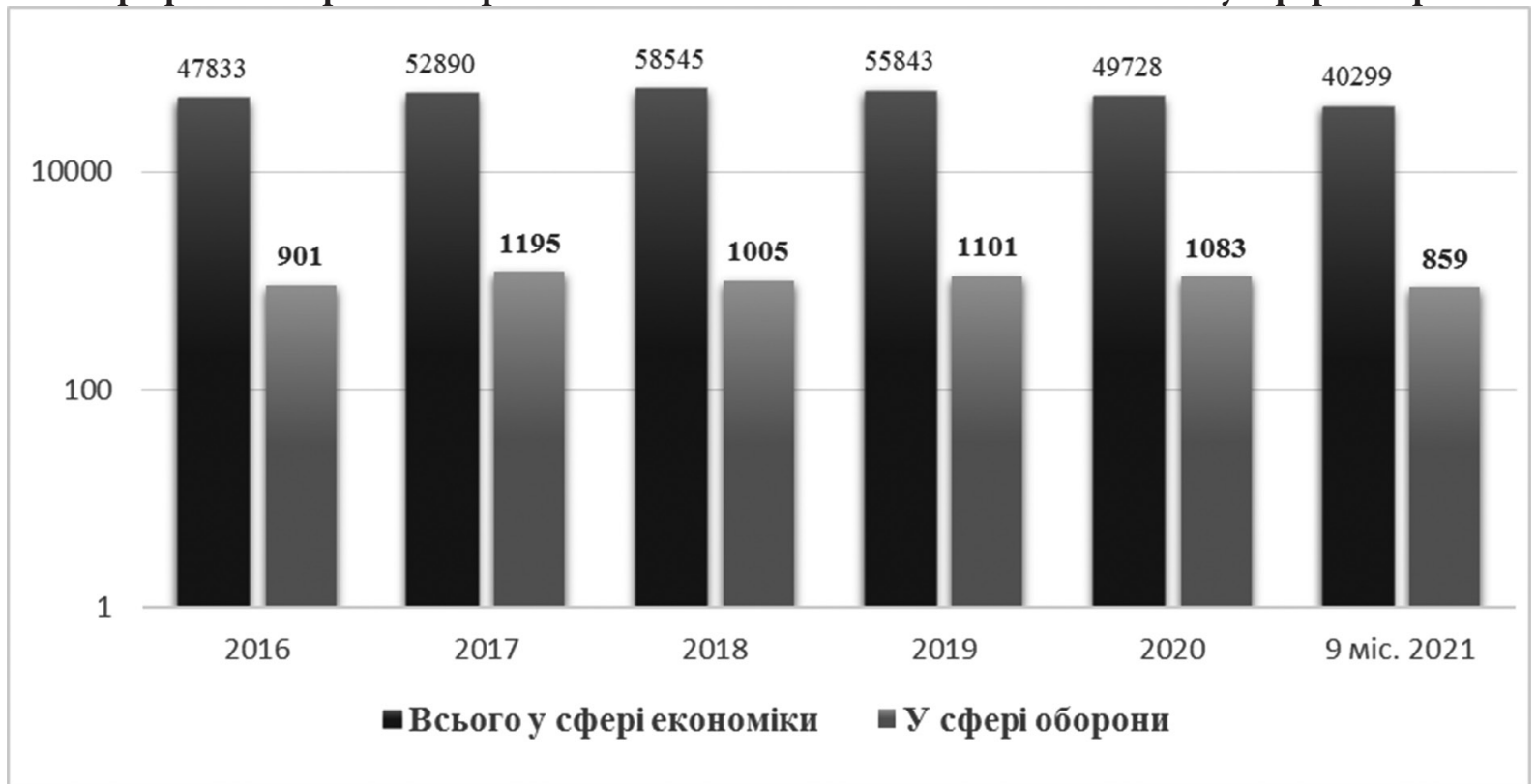

Певна річ, така категорія, як «Діяльність у сфері оборони», по якій формуються узагальнені відомості про зареєстрований рівень кримінальних правопорушень, вчинених на підприємствах, установах, організаціях за видами економічної діяльності (форма статистичного обліку Ф №1-О3), є ширшою за діяльність підприємств, установ та організацій, що складають ОПК України. До неї також входить і сфера діяльності підприємств, установ, організацій, підпорядкованих Міністерству оборони України, структурних підрозділів останнього, у т.ч. військових частин тощо. Водночас, здійснений нами аналіз слідчої та судової практики дає підстави для висновку, що не менш як $95 \%$ усіх кримінальних правопорушень економічної спрямованості, що потраплять до статистичного обліку за категорією «Діяльність у сфері оборони», вчиняються на об'єктах ОПК України. Тому загалом вважаємо відповідні статистичні показники придатними для обробки в контексті досліджуваної нами проблематики.

У зв'язку з цим звернімо увагу передусім на відсутність усталеної тенденції відтворення економічних кримінальних правопорушень у сфері ОПК. На жаль, до 2016 р. статистичний облік кримінальних правопорушень за формою Ф №1-О3 не здійсню- вався, через що ми не маємо змоги охопити статистичним спостереженням довший динамічний ряд, на якому 6 можна було гіпотетично виявити деяку закономірність, тенденційність. Аналізований же неповний шестирічний період, натомість, не дає такої можливості. Можемо бачити хвилеподібну динаміку, зміну рівня, показників приросту зареєстрованих кримінальних правопорушень в ОПК від року в рік, що говорить радше про ефективність діяльності правоохоронних органів щодо виявлення цих правопорушень та, відтак, про їх високий рівень латентності. Загалом же протягом повного п'ятирічного періоду (2016-2020 рр.) було зареєстровано 264839 кримінальних правопорушень економічної спрямованості загалом, з яких 5285 - у сфері оборони, що складає близько 2 \% від загального обсягу економічної злочинності.

На відміну від економічної злочинності у сфері оборони, динаміка загальної економічної злочинності демонструє коливання в межах дворічних інтервалів позитивних i негативних значень темпів приросту. При цьому найвищий позитивний показник темпу приросту щодо базового 2016 р. у загальній економічній злочинності припав на 2018 p. і склав 22,4\%, а найнижчий негативний на 2020 р. - 3,9 \%. Аналогічна картина дина- 


\section{Кримінальне право, кримінальний процес та криміналістика}

міки виявляється і при застосуванні ланцюгового методу обчислення: у 2018 р. і склав 10,7 \% по відношенню до 2017 р., а у 2020 р. - -10,9\% по відношенню до 2019 р. Натомість динаміка економічних кримінальних правопорушень у сфері оборони у 2018 р. навпаки засвідчила найнижчі показники ряду (за винятком базисного 2016 р.). Так, темп приросту, розрахований ланцюговим способом, у цей рік склав - 15,9\%. Водночас найвищим цей показник був у 2017 р. - 32,6\%. Загалом же для динаміки відтворення економічних кримінальних правопорушень у сфері оборони характерні щорічні коливання позитивних і негативних значень темпів зростання і приросту відповідно.

Aле при тому не можна не відмітити єдину спільну для двох видів кримінальних правопорушень рису динаміки - загальна тенденція до зростання у порівнянні з 2016 р., за якою «оборонка» демонструє вищі показники. Так, середньорічний приріст, розрахований базисним методом для загальної економічної злочинності, становить 13,4\%, тоді як для оборонної сфери - 21,6 \%, а розрахований ланцюговим методом - 1,5\% та 6,2\% відповідно.

У структурі кримінальних практик, які відтворюються на підприємствах, установах, організаціях оборонної сфери, переважають ті, що можуть бути віднесені до економічних (див. діаграму 2).

Як можна бачити з діаграми 2, корупційна злочинність (а у структурі кримінальних правопорушень у сфері службової діяльності та професійної діяльності, пов'язаної з наданням публічних послуг ті, що можуть бути віднесені до корупційних, складають більше 76 \%) - це функціональне осердя кримінальних практик у сфері оборони, що, в принципі, цілком очікувано. І очікувано це перш за все тому, що, як нами було зазначено вище, ОПК - колосальне за своїми масштабами ресурсне поле, у якому ключову роль відіграє державне майно, бюджетні кошти, оборонні закупівлі. 3 огляду на це вважаємо за доцільне більш детально зупинитись на цьому

Діаграма 2

Графічне зображення структури злочинності у сфері діяльності оборонних підприємств, установ, організацій

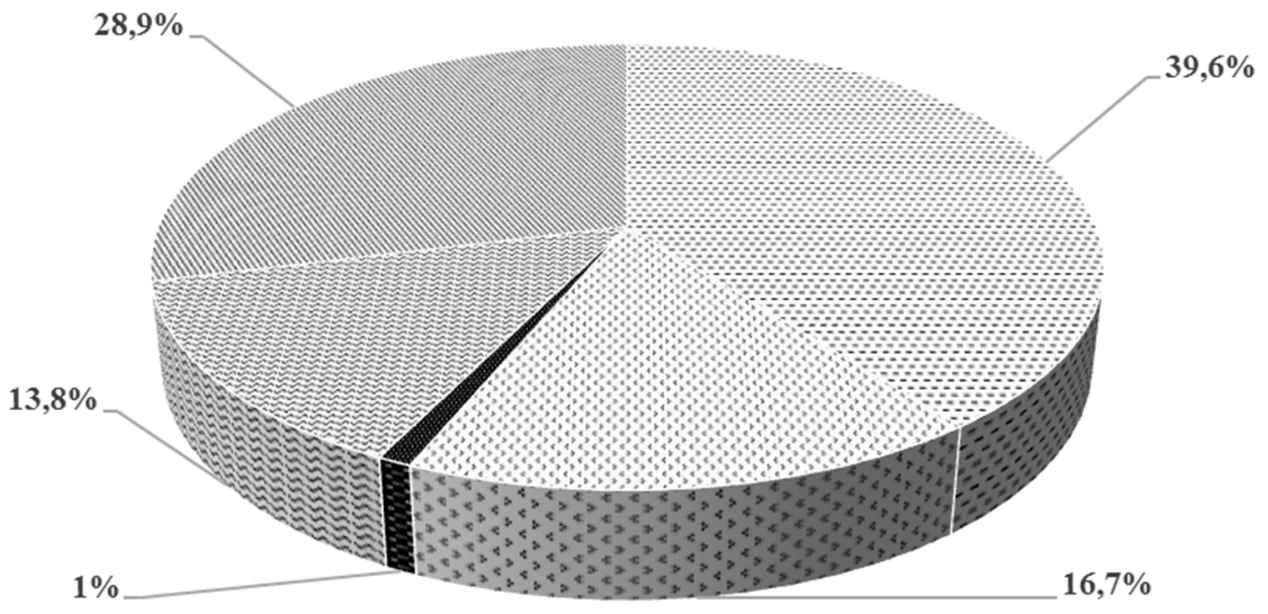

- У сфері службової діяльності

Ст. 191 КК України

๙ У сфері господарської діяльності

$\approx$ Інші кримінальні правопорушення проти власності

« Інші кримінальні правопорушення 
сегменті злочинності, надавши опис особливостей ії відтворення.

Системні корупційні практики, злочинні промисли, оформлені в корупційні схеми, що охоплюють найвищий політичний рівень прийняття рішень про кадровий склад державних підприємств ОПК, інших органів та установ, дотичних до регулювання їх діяльності, розміщення та виконання державного оборонного замовлення, оборонних закупівель (у тому числі і зокрема - у приватному секторі ОПК), керування відповідними фінансовими потоками. Важливо наголосити на тому, що особливістю корупційних схем взагалі та в ОПК, зокрема, $\epsilon$ те, що їх функціонування принципово не залежить від персонального складу учасників. Симптоматичним є те, що протягом 2014-2020 рр. за фактами корупційних злочинів, де фігурантами є службові особи підприємств ОПК, заведено більше 530 кримінальних проваджень. Втім, це не призвело до руйнації схем. Тому вони є вельми стійкими, трансрежимними (у політичному сенсі), відтворюються за закономірностями інтеракції, беруть участь у міжпоколінному транзиті менеджерів на рівні вищих і центральних органів державної виконавчої влади, окремих підприємств.

Однак, корупція в ОПК - не відокремлена проблема; вона щільно переплітається 3 політичною корупцією, корупцією в правоохоронних органах. Тому варто констатувати стійкість інституціоналізованих корупиійних практик в ОПК. Це підтверджується як зібраними нами експертними оцінками колишніх менеджерів підприємств цього комплексу, правоохоронців (працівників Департаменту стратегічних розслідувань Національної поліції та його інституційних попередників (ДЗЕ, ДСБЕЗ), СБУ), так і моніторингом публікацій у засобах масової інформації, журналістських розслідувань, судової практики. Вони наочно засвідчують, що, незважаючи на змінювані політичні еліти, зміни конфігурацій, розстановки сил у «глибинній державі», публічних порядках, режимах, які ними репрезентувалися, завжди основні «ребра жорсткості» вказаних практик формувалися та забезпечувалися за рахунок окремої лінії адміністрування, центри яких розподілялися в оборонному квартеті - Адміністрація Президента (Офіс Президента), Міністерство оборони, Рада національної безпеки і оборони, парламентський комітет 3 національної безпеки, оборони та розвідки (у різних історико-політичних назвах цих органів). Спеціалізоване міністерство (у різні періоди часу - 3 різними назвами) завше відігравало другорядну, здебільшого технічну роль. Зрозуміло, існували та існують допоміжні суб'єкти, сателіти, що також живляться від оборонних кримінальних стримів, однак не визначають їх базові параметри. До них належать правоохоронні органи, до завдань яких безпосередньо належить виявлення та припинення злочинів в ОПК, а також ті, що є суб'єктами оборонного замовлення.

Здійснений нами аналіз і узагальнення емпіричної бази дозволяє виділити чотири основні напрями реалізації корупційних схем в ОПК: 1) розтрата ввіреного або такого, що перебуває у віданні майна - обладнання підприємств ОПК; 2) незаконний експорт товарів військового та подвійного призначення; 3) привласнення виділених за оборонним замовленням коштів на закупівлю товарів і послуг у фіктивних підприємств, неіснуючих товарів і послуг; 4) закупівлі товарів і послуг за завищеними цінами (зазвичай використовується декілька фірмпосередників), у тому числі й імпортні операції. Наведемо декілька прикладів того, як працюють ті схеми.

Так, у листопаді 2014 р. гр. К. звернувся до гр. М. з пропозицією підшукати для нього юридичну особу, акредитовану для проведення поставок товарів для підприємств ДК «Укроборонпром», 3 метою укладення від імені такої юридичної особи фіктивних договорів поставки запасних частин та комплектуючих виробів до бронетанкової техніки, зокрема 3 державним підприємством «Миколаївський бронетанковий завод», та подальшого обготівкування через неї грошових коштів, одержаних від державних підприємств ОПК нібито за поставку їм запасних частин та комплектуючих виробів до бронетанкової техніки, за що директор такої юридичної особи буде отримувати від нього неправомірну вигоду, розмір якої буде об- 


\section{Кримінальне право, кримінальний процес та криміналістика}

говорено додатково. За указане, посередництво К. пообіцяв М. надати грошову винагороду, на що вона погодилась. У період 3 22.12.2014 р. по 22.04.2015 р. під час особистих зустрічей та неодноразових телефонних розмов, М. повідомляв гр. Ф., директора ДП «Миколаївський бронетанковий завод», що постачати товари не потрібно, натомість йому необхідно обготівковувати та передавати грошові кошти, які державне підприємство перераховуватиме на розрахунковий рахунок ТОВ «АН CITI-CEPBIC», на виконання укладених договорів, за що він, $\Phi$., одержуватиме неправомірну вигоду. Ф. звернувся до СБУ і кримінальне правопорушення було припинено [1].

Ідентичною за змістом 6 корупційна схема, організована керівниками ДП «Укрінмаш». Досудовим розслідування встановилено, що впродовж 2014-2016 рр. керівництво «Укрінмашу» організувало постачання за кордон продукції, виробленої на інших підприємствах «Укроборонпрому», за участі приватної компанії, кінцевим вигодонабувачем якої була особа, що мала дружні взаємини 3 одним із топменеджерів держпідприємства. «Укрінмаш» уклав із цією компанією агентську угоду з супроводу зовнішньоекономічних контрактів, за що та справно отримувала від «Укрінмашу» кошти. Однак, як встановило слідство, відповідні послуги фактично не надавались, а акти виконаних робіт підробляли за участі службових осіб «Укрінмашу». Загалом слідство встановило, що упродовж 2014-2016 рр. «Укроборонпром» незаконно перерахував приватній компанії понад 140 тис. євро [2].

Іншою корупційною схемою, що активно використовується на різних підприємствах ОПК, є привласнення державного майна (грошових коштів) через документальне проведення біктивних закупівель за завищеними иінами, аніж фактично здійснювані позадокументальні закупівлі при постачанні необхідних товарів на підприємства ОПК. Ї̈ особливостями є: а) налагодження корупційних зв’ язків між представниками щонайменше двох (а частіше - трьох) суб'єктів підприємницької діяльності, один з яких є суб'єктом ОПК та замовляе виконання робіт чи постачання товарів задля виконання оборонного замов- лення (оборонної закупівлі), а інший (інші) - виконавець чи, відповідно, постачальник, який забезпечує відповідний обсяг послуг/ товарів за фактично нижчими цінами, аніж офіційно зафіксовані. Зазвичай один суб'єкт господарювання (інколи - фіктивне підприємство) забезпечує документальну картину угоди із вказаними завищеними цінами, реально не постачаючи жодного товару та не надаючи жодних послуг, а інший без документального оформлення здійснює відповідні роботи чи реалізує товар; б) залучення посередників, що забезпечують комунікацію між представниками різних бізнес-структур; в) вчинення супутніх кримінальних правопорушень, передбачених ст. ст. 358, 366 КК України; д) подальша легалізація отриманих доходів (ст. 209 КК України). Одним 3 маркерів реалізації цієї схеми є припинення діяльності фіктивного підприємства практично одразу (з мінімальним проміжком часу) після квазіправового оформлення угоди про начебто постачання товарів чи виконання робіт. Мета припинення - мінімізація можливості документування злочинної діяльності, знищення слідів злочину.

До такого ж роду корупційних схем із фактичною закупівлею товарів за цінами, нижчими, ніж ті, що проводяться за офіційною документацією (обіиійна закупівля за завищеними иінами) належить і злочинна діяльність, що проявилася за таких обставин: у 2014 р. директор ДП «Авіакон», його заступник та представник офшорної компанії Westan Group Associates Ltd організували дві закупівлі в обхід передбачених стандартів та процедур. За умовами першої Westan Group Associates Ltd поставила ДП «Авіакон» 12 паливних баків до гвинтокрилів Мі-24 за 288 тис. дол. США, закуплених у безпосереднього виробника, розташованого в Грузії, за вдвічі меншою ціною - 144 тис. дол. СІІА. Згодом ДП «Авіакон» уклало з Westan Group Associates Ltd інший договір - на постачання 200 баків також за ціною вдвічі вищою від закупівлі у грузинського постачальника. Однак, останній зміг поставити лише 85 баків, які Westan Group Associates Ltd придбала за 1,02 млн дол. США та перепродала «Авіакону» за 2,04 млн дол. СШША. Договори між ДП «Авіакон» та Westan Group Associates 
Ltd на постачання всіх паливних баків укладалися без попереднього аналізу ринку цін та отримання пропозицій інших постачальників, без залучення відповідальних за вказаний напрямок роботи працівників заводу [3]. Схожою за змістом корупційною схемою є закупівля товарів нижчої якості, аніж передбачено замовленням, за цінами товарів належної якості.

Описані корупційні схеми репрезентують функціональну характеристику основного сегменту злочинності у сфері ОПК. Натомість для повноти уявлення про феномен останньої варто також вказати і на те, що вказані схеми за визначенням є проявами організованої злочинності. При чому особливістю організованої злочинності у сфері ОПК є те, що, по-перше, вона характеризується підвищеною суспільною небезпечністю $з$ огляду на предмет відповідних кримінальних практик та, по-друге, має складну рівневу будову з виходом на інтегративні економіко-політичні комплекси. Що мається на увазі?

Передусім те, що варто вести мову про різні види організованих злочинних угрупувань у сфері ОПК за ступенем їх впливу на народне господарство, національну безпеку. Ïх можна виділити принаймні три: нижчий, середній та вищий.

Нижчий рівень організованої корупиійної злочинності в ОПК - це об'єктовий рівень, який обмежується масштабами одного підприємства. Типові корупційні схеми - щодо незаконного привласнення чи розтрати майна через необгрунтоване призначення премій, необгрунтоване списання та придбання за заниженими цінами майна підприємства тощо. Зазвичай чисельний склад групи, яка реалізує подібні схеми, - невеликий, 2-5 осіб. Їх діяльність здебільшого не складає небезпеки для всієї галузі та похідної від неї сфери - оборонної, стану функціональності війська (Збройних Сил України, Національної гвардії).

Середній рівень організованої корупиійної злочинності у сфері ОПК характеризується кооперацією зусиль представників й ін $\Phi$ раструктурних, фінансових, формально-документарних можливостей кількох юридичних осіб, кожна з яких або деякі з яких вхо- дять до складу ОПК. Це - основний рівень реалізації більшості схем із закупівлями за завищеними цінами, із придбанням товарів і прийняттям робіт неналежної кількості, якості тощо. Обсяг злочинних угрупувань коливається вже від 5 до 15 осіб. У низці випадків на цьому рівні відбувається налагодження корупційних зв'язків з керівниками місцевих військових частин, до яких постачається бойова техніка (нова чи відремонтована) та/або з представниками місцевих правоохоронних органів для забезпечення прикриття кримінально протиправної діяльності.

Вищий рівень організованої корупиійної злочинності у сфері ОПК - найбільш небезпечний і найбільш труднодоступний для правоохоронних органів. Причина тому вищий рівень політичного прикриття. На цьому рівні корупційні схеми функціонально й персонально замкнені на представниках вищих, центральних органах державної влади. Відтворення системної корупції на цьому рівні є однією з причин фактичного знищення стратегування в управлінні галуззю зі всіма наслідками, що з цього випливають.

Цілком зрозуміло, що вищий рівень відтворення організованої корупційної злочинності в ОПК - це не самостійна проблема, ані у практичному кримінально-превентивному, ані у гноселогічному значенні. Ця проблема дотична і $є$ похідною від проблеми політичної злочинності в державі, від зрощення спочатку загальнокримінальної злочинності із економічною, а згодом економічної із політичною. Коріння цих метаморфоз вітчизняної злочинності сягають 90-х років минулого сторіччя, періоду первинного кримінального накопичення капіталу, за рахунок якого відбувалася інституціоналізація політичної системи. Тож руйнація цих корупційно-інституційних узвичаєнь - справа набагато вищого масштабу осмислення, аніж виключно протидія злочинності в ОПК України. А тому наша задача в цьому аспекті полягає не стільки у вирішенні цих проблем, скільки у визначенні їх (злочинності в ОПК) комплексного, системного характеру, що має вихід на феномен політичної злочинності. 


\section{Кримінальне право, кримінальний процес та криміналістика}

Варто кілька слів сказати і про корупційну складову функціонування ОПК у його торгівельному сегменті, зокрема у сфері оборонних закупівель, у тому числі імпорті озброєнь. Як засвідчують експертні оцінки, на цей час склався вражаючий дисбаланс у розвитку ОПК, пов'язаний із тим, що в середині комплексу діють непрозорі, занадто утаємничені та орієнтовані переважно на державні підприємства, умови. Найбільш негативними наслідками цього є неконкурентоспроможні умови для приватних підприємств та непривабливість українського ринку для іноземних компаній. $95 \%$ номенклатури озброєнь і військової техніки закуповуються без конкурентних процедур [4]. Відсутність останніх, нестача транспаретності розподілу бюджетних засобів на оборонні закупівлі, ручний механізм здійснення останніх, з одного боку, пояснюеться високою чутливістю цього пласту торгівельних відносин до проблем національної безпеки і обороноздатності. 3 іншого, цими факторами прикриваються найбільш проблемні зони привласнення державних коштів через механізми так званих «відкатів» на оборонних закупівлях.

Окремо наголосимо на тому, що досить тривалий час створювалося поживне підгрунтя для консервування високих обсягів імпортизації високоточного озброєння, що в умовах непрозорого прийняття рішень набуває явного корупційного відтінку. До прикладу, Міністерство оборони України у 2015 р. закупило 5 безпілотних авіаційних комплесів (БАК) мікрокласу вартістю 270 тис. євро кожен. За експертними ж даними, технічні характеристики тієї ж «урії (БАК вітчизняного виробництва)» у кілька разів перевищують тактико-технічні характеристики закуплених БАК, а вартість вітчизняного виробу вдвічі нижча. Втім, загальні закупки військовим відомством БАК такі мізерні, що й цифру небажано озвучувати. Скажемо тільки, що «Фурії», які чудово зарекомендували себе на фронті, у 2016 році не закуповувалися взагалі. Ба більше, у затверджених Генштабом змінах до плану оборонних закупівель «Фурія» для ракетних військ i артилерії (фактично БАК - навідник i коректувальник артилерії) прописаний у закупках за спецфондом. Тобто шанс цих безпілотників потрапити у війська, попри вкрай високу потребу, фактично мінімальний. Загалом же, керівники приватних підприємств свідчать: для закупівлі іноземних озброєнь і військових товарів у Міністерство оборони України досить подати офіційний «інвойс», і «відомству все одно, яка вартість, коли є рішення закуповувати». Якщо ж ідеться про закупівлю вітчизняних товарів, негайно починається низка нескінченних перевірок, супроводу, приймань... [4].

Певна річ, корупція - не єдиний фактор прийняття недостатньо обгрунтованих (3 економічної та суто оборонної точок зору) рішень щодо оборонних закупівель, зокрема імпорту озброєнь і військових товарів. Не маємо відкидати і банальну некомпетентність, недоліки у системі управління оборонними закупівлями, коли можливості вітчизняного ОПК не в повній мірі є відомими. Однак - це фактори іншого формату. Нас же цікавить саме корупційна етіологія часткової дисфункції інституту оборонних закупівель, природа якого в принципі не передбачає іншого варіанту, окрім системного характеру корупційної злочинної діяльності, до організації якої залучають представники вищого і центрального рівнів апарату держави.

Разом 3 тим, феномен злочинності в ОПК, окрім системно-корупційних і властивих їм акцесорних кримінальних практик, доповнюеться також і ситуативними корупційними злочинами, які хоча і можуть набувати рис корупційних схем, однак які, взяті окремо, за своїм масштабом, тривалістю діяльності та кількістю залучених осіб не складають загроз економічній безпеці галузевого масштабу, загроз обороноздатності, здійснюються поза злочинним контролем, управлінням з боку керівництва галузі, політичних еліт країни. Так, до прикладу, гр. Б., працюючи на посаді фінансового директора ДП «171 Чернігівський ремонтний завод», 3 метою отримання неправомірної вигоди, вступила у змову із заступником директора цього ж підприємства гр. У., який був головою комісії по контролю за утриманням i списанням основних засобів виробництва та, у результаті чого 16.01.2013 р., за по- 
передньою змовою з гр. М., діючи всупереч інтересам служби, одержала від нього неправомірну вигоду в розмірі 4500 грн. за підписання договору купівлі-продажу№ 97/2012 від 12.12.2012 р. на продаж двох верстатів як таких, що підлягають списанню [5]. Втім, навіть і ситуативні корупційні злочини виявляються вельми поширеними в аналізованій сфері завдяки існуванню низки іманентних факторів корупції - корупційних ризиків.

У зв'язку з цим зрозумілим та обгрунтованим видається положення абз. 2 п. 2, п. 5 Рішення РНБО «Про реформування оборонно-промислового комплексу та підвищення рівня прозорості виконання державного оборонного замовлення» від 06.03.2019 р. щодо необхідності термінового забезпечення усунення корупційних ризиків, підвищення рівня прозорості та посилення контролю 3 боку держави і громадськості за діяльністю ДК «Укроборонпром» та інших державних підприємств ОПК, а також про рекомендування Генеральній прокуратурі України, Службі безпеки України, Національному антикорупційному бюро України, Державному бюро розслідувань здійснити перевірку і надати правову оцінку фактам, викладеним у засобах масової інформації, щодо порушень у сфері закупівель продукції, робіт, послуг оборонного призначення [6].

\section{Висновки}

Підсумовуючи, зауважимо, що корупційна злочинність в ОПК постала справжнім викликом існуванню галузі. Aле не тільки викликом кримінально-економічного порядку, а й справжньою загрозою національній безпеці, зважаючи на функціональну спрямованість самого ОПК і кризового, конфліктного суспільно-політичного контексту, пов'язаного з перманентною агресією РФ щодо України. Дослідження засвідчило складно структуровану феноменологію корупційної злочинності в ОПК, що включає розмаїття корупційних схем як у виробничому, так і торгівельному сегментах, їх відтворення на всіх рівнях, включаючи вищий політичний. Через це констатовано наявність генетичних зв’язків інституціоналізованих корупційних практик в ОПК та полі- тичної корупції в державі. Ця обставина виводить на розуміння необхідності розробки комплексної стратегії протидії злочинності в ОПК, що включатиме в себе низку напрямів і рівнів обструкції політико-кримінальних практик, зниження впливу олігархату на політичну систему України.

\section{1. Вирок $\stackrel{\text { Мiтература }}{\text { Шевченківсько- }}$} го районного суду м. Києва. Справа№ 761/28611/15-к. URL : https://reyestr.court. gov.ua/Review/53832293 (дата звернення: 10.09.2021).

2. Корупція на «Укрінмаш»: матеріали відкрито / Матеріали Національного антикорупційного бюро України. URL: https://nabu.gov.ua/novyny/korupciya-naukrinmash-materialy-vidkryto (дата звернення: 13.10.2021).

3. Справа Конотопського авіаремонтного заводу «Авіакон» / Матеріали Національного антикорупційного бюро України. 16.12.2019. URL : https://nabu.gov.ua/novyny/ sprava-konotopskogo-aviaremontnogozavodu-aviakon (дата звернення: 21.10.2021).

4. Регулювання закупівлі, експорту/імпорту озброєнь і військової техніки в Україні. Особливості і шляхи удосконалення : Доповідь Центру досліджень армії, конверсії та роззброєння (січень 2017 р.) / Під ред. В. Бадрака. URL : https://media. neliti.com/media/publications/324123-analysisof-the-state-of-financing-of-th-e025094e.pdf (дата звернення: 04.08.2021).

5. Вирок Деснянського районного суду м. Чернігова. Справа№ 750/2721/13-к. URL : https://reyestr.court. gov.ua/Review/32282253 (дата звернення: 19.08.2021).

6. Про реформування обороннопромислового комплексу та підвищення рівня прозорості виконання державного оборонного замовлення : Рішення Ради національної безпеки і оборони України від 06.03.2019 р. ; Указ Президента України 15.03.2019 p. № 79/2019. URL : https://zakon. rada.gov.ua/laws/show/n0001525-19 (дата звернення: 20.03.2020). 
Serhiy O. KOZHUSHKO, graduate student

(Kharkiv National University of Internal Affairs, Kharkiv, Ukraine)

THE STATE OF CORRUPTION CRIME IN THE DEFENSE-INDUSTRIAL COMPLEX OF UKRAINE

The article is devoted to the problems of the current state of corruption crime in the defense industry of Ukraine. The description of the level, dynamics of this type of crime in the context of general economic crime and economic crime in the field of defense is established and provided. The most common corruption schemes are described. Reproduction of corruption crime in the defense industry has been identified and argued at the lower (object), middle, and higher, system levels.

The study showed a complex structured phenomenology of corruption crime in the defense industry, which includes a variety of corruption schemes, both in the production and trade segments, their reproduction at all levels, including higher political. The analysis and generalization of the empirical base allowed us to identify four main areas of implementation of corruption schemes in the defense industry: 1) waste of entrusted or in charge of property - equipment of defense industry enterprises; 2) illegal export of military and dual-use goods; 3) appropriation of funds allocated under the defense order for the purchase of goods and services from fictitious enterprises, non-existent goods and services; 4) purchase of goods and services at inflated prices (usually used by several intermediary firms), including import operations.

It has been established that the lowest level of organized corruption crime in the defense industry is an object level, which is limited to the scale of one enterprise. The average level of organized corruption crime in the field of defense industry is characterized by the cooperation of efforts of representatives and infrastructural, financial, formal and documentary capabilities of several legal entities, each or some of which are part of the defense industry. The highest level of organized corruption crime in the field of defense industry is the most dangerous and most difficult to access for law enforcement agencies. The reason is the higher level of political cover. At this level, corruption schemes are functionally and personally closed to representatives of higher, central state authorities. The reproduction of systemic corruption at this level is one of the reasons for the de facto destruction of strategy in the management of the industry, with all the ensuing consequences.

As a result, there are genetic links between institutionalized corrupt practices in the defense industry and political corruption in the country. This circumstance suggests the need to develop a comprehensive strategy to combat crime in the defense industry, which will include a number of areas and levels of obstruction of political and criminal practices, reducing the influence of the oligarchs on the political system of Ukraine.

Key words: defense-industrial complex, economic crime, organized crime, state, corruption, corruption scheme. 